\title{
5
}

\section{STATE EXPENDITURE IN NIGERIA: A HISTORICAL SKETCH, 1960-1983}

\author{
Festus O. Egwaikhide
}

\section{INTRODUCTION}

In general, the role of the state is enormous in developing countries. This is particularly so because of the failure of the free market system to achieve Pareto-efficiency in the areas of public goods, externalities, income and wealth distribution, price stability, as well as economic growth and development. These and other related factors constitute the basis for economic planning and the economic foundation of a mixed economy in the Third World.

One important way in which the State intervenes in the economy is through its expenditure programme. Thus, an important measure of the size of government in the economy is the magnitude of public expenditure (or state expenditure as a percentage of Gross Domestic Product, GDP). Using this indicator, it can be said that the participation of government in the Nigerian economy has been substantial. This is true, especially when it is realised that the total planned public expenditure leaped dramatically from about N1.35 billion in the First National Development Plan (1962/68) to N82.0 billion in the Fourth Plan (1981/85).

State expenditure has several effects on the national economy. And a number of economic, social and political factors determine public outlay. Previous studies on this important subject in Nigeria have generally explained the growth of government outlays in terms of rapid economic growth and population, by implication, the underlying socioeconomic and political factors are ignored.

This article charts a different course by relating the growth of public spending to historical factors. Our focus is on federal expenditure during the twenty-four years, 196083. Some of the key effects of state expenditure are noted. The rest of the paper is divided into four sections. Section Two examines trends in government expenditure. State expenditure during military regimes is discussed in Section Three. Section Four is devoted to expenditures under civil rule. In the final Section, we present the concluding remarks. 
50 Annals of the Social Science Council of Nigeria, No.4, 1992.

\section{GROWTH GOVERNMENT EXPENDITURE IN NIGERIA}

Public outlay has grown considerably since the achievement of political independence in 1960. In absolute terms, the total government budget, federal and state governments' expenditure combined, increased from N336.3 million to N21.2 billion between 1961 and 1983 an increase of approximately 6,204\%. In te ${ }^{r} \mathrm{~ms}$ of mean yearly growth rate, public expenditure grew at $15 \%$ in the period. State expenditure, as a percentage of GDP also rose substantially. It jumped from only 15\% of GDP (at current prices) in 1961 to $30.6 \%$ in 1970, and by 1983, it had exceeded 41\% of GDP (see Table 1 in the Appendix). The trite conclusion here is that government expenditure increased faster than GDP, a reflection of Wagner's law of ever-increasing state activity."

Public spending was generally moderate in the period 1962-66, that is, the precivil war years. Although, total expenditure fell in 1967, the year the civil war started, it however increased thereafter. But after the civil strife in January 1970, government outlay fell slightly in 1971, and rose thereafter. This development is in line with the Peacock-Wiseman "displacement effect" hypothesis, since soon after the war, expenditure fell and did not return to the pre-war level. ${ }^{3}$ Since our main focus is on federal government expenditure, it is important to present similar data relating to it.

Between 1960 and 1980, the federal government budget increased remarkably. In absolute value, the total federal outlay leaped from barely N164 million in 1961 to slightly above N14.0 billion by 1980 (see Table 2 in the Appendix). On the average, federal expenditure was generally moderate before the civil war. The central government's outlay, however, rose during the war and even increased remarkably after the civil disturbance. The rise in defence spending during the war years explains the trend in the overall government outlay.

After 1970, the federal government expenditure vastly expanded because of the fortuitous wealth from oil and the commitment to reconstruction programmes by the federal military government. Trends in recurrent and capital expenditures of the State, reveal that prior to 1974 , recurrent expenditure generally exceeded capital budgets. The overtaking of consumption expenditure by capital outlay from 1974 was due to various grandiose projects embarked upon by government. The functional composition of expenditure indicates that administration outlay has been particularly large. This may have been due to huge defence spending in addition to the expansion of the State's bureaucracy.

\section{STATE EXPENDITURE UNDER THE MILITARY, 1966-79}

The first military intervention in Nigerian politics dates back to 1966. And the military leadership which managed the affairs of the State since then did not hand over to a civilian government until October 1979. Thus, our discussion of public expenditures under military regime spans thirteen years.

As we indicated previously, the civil strife occurred from 1967 to early 1970. With this, many people, especially young men, were conscripted into the 


\section{State Expenditure in Nigeria: A Historical Sketch 51}

armed forces. This automatically raised defence spending, as wages and salaries had to be paid to the large number of newly enlisted soldiers. Together with this was the purchase of war and war-related equipment. The collective effect of these was increased government spending. The incongruity between the State's revenue and expenditure generated budget deficit, and this was financed partly from bank credit. Capital development projects were adversely affected by the war. This possibly explains why capital expenditure as a percentage of aggregate federal spending fell progressively from $35.4 \%$ in 1967 to $23 \%$ in 1971 .

Correspondingly, there was massive dislocation of most economic activities, particularly the productive sector of the economy, during the period. Specifically, the index of food production fell from 103 in 1963 to 80 in 1968 (using 1960 as the base year) and the share of agriculture in GDP (valued at current prices) declined from 52.6 to $36 \%$ between 1965 and 1970. It can be argued, therefore, that the prosecution of the civil war marked the beginning of the Nigerian food crisis.

After the civil crisis in early 1970, the military regime under the leadership of Major General Yakubu Gowon was pre-occupied with rehabilitation, reconstruction and development 'programmes. These pre-occupations were reflected in planned public expenditure of about N2.0 billion in the 1970-74 Second Plan. A critical constraint to the pursuit of these and other related programmes was inadequate resources - revenue in particular. Fortunately, the financial constraint of government became relaxed with the sharp increases in crude petroleum prices in the world oil market. It was almost incredible that the federally collected revenue increased about sevenfold from N633.3 million to N4.5 billion between 1970 and 1974. Several reasons accounted for this. Among- them were various petroleum tax reforms. These significantly raised the federal government's share per barrel of crude oil sales.

With these, the ambitions of planners and other social decision makers grew more than proportionately to the available revenue. Indeed, emphases shifted to grandiose projects. Not surprisingly, federal expenditure more than doubled between 1970 and 1974, when it rose from NS38.8 million to N2.1 billion.

It is important to reflect on the 1973-74 sahelian drought which adversely affected food production. The resultant effects of this development were rapid increases in food prices. The pent-up aggregate demand caused by the civil war also exerted pressures on food prices. In consequence, labour pressurised for increases in wages/salaries and benefits. The Adebo wage review panel which unified the salary structure in the public sector was the immediate response to labour demands for wage increases.

Similarly, the government implemented the wages and salaries' award recommended by the Public Service Commission headed by Chief Udoji in ,1975. About N859 million was used to pay the arrears of civil servants of all categories in the exercise. Even the private sector approved increases of $30 \%$ or more and paid arrears of almost N292 million to its employees. ${ }^{11}$ The implementation of 'Udoji Award' raised the wage bill of the public sector by about $50 \% .^{12}$ 


\section{Annals of the Social Science Council of Nigeria, No. 4,1992.}

The promulgation of the Nigerian Enterprises Promotion (NEP) Decree in 1972 (amended in 1977), enhanced government's involvement in the economy. With this development, direct government involvement in agriculture (for example, fertilizer import), industry, transport and communications, and even construction deepened. But, most of the State's enterprises did not only find it difficult to cover operating costs, they were also heavily politicised. This possibly made their structure of management very weak. Overstaffing, lack of labour performance and corruption were also common phenomena of parapublic firms. The losses incurred by these firms were financed from public budgets. Perhaps, it may be insightful to note that the deepening involvement of the State in the economy during this period was engendered largely by the massive earnings from crude oil export.

Partly because of the increased demand for state creation and probably as part of the decision to internalise the benefits from a non-renewable resource (oil), the federal military government created seven additional states in 1976. This meant the expansion of the State's bureaucracy. Added to this was the extension of basic infrastructures such as roads, electricity and communications, to these states. These combined to raise public budget, particularly capital outlay, between 1974 and 1980 (see Table 2).

Emphasis was also placed on the development of human capital, as reflected in the number of educational institutions established in the 1970s. For example, there was a dramatic increase in the number of federal universities and student enrolment. The number of federal government-owned universities which was six as at 1970, rose to thirteen by 1975 . Correspondingly, the number of federal secondary schools, colleges of education and polytechnics increased markedly. It was not surprising, therefore, that the enrolment in Nigerian universities rose sharply from 14,468 in 1970/71 to 40,914 in the 1976/77 sessions. The Universal Primary Education (UPE) also became operational in the 1976/77 session. The provision of basic infrastructural facilities for these programmes and other federally-owned educational institutions added to expand capital expenditures of the federal government capital expenditure rose from N200.5 million in 1970 to more than N4.0 billion by 1976 .

There are other key factors that may not be ignored. As part of the strategy to raise the benefits from oil exploration and exploitation, and «Lo to facilitate technology transfer to the oil industry, the second refinery at Warri was proposed in the Second Development Plan (1970/74). This was not completed until 1978, but its total completion cost jumped from N18 million proposed in the Plan to almost N525 million, though, its installed capacity doubled from 2.5 million metric tons to 5 million metric tons. ${ }^{1}$ This has been attributed largely to delays in project execution arising from conflict of interests, especially between comprador and bureaucratic bourgeoisie in the various ministries concerned with this project.

Even so, public sector projects during the oil boom were hurriedly prepared and executed haphazardly. This attests to the fact that the military had no well-defined economic objectives ${ }^{15}$. Of course, it also partly explains why the military government committed about N170 million to construct the Lagos-Ibadan (about $150 \mathrm{~km}$ ) expressway that was completed in 1978. 


\section{State Expenditure in Nigeria: A Historical Sketch 53}

Similarly, several fly-overs were built in Lagos, and the country hosted the Black Festival of Art and Culture (FESTAC) in 1977. The construction of several sea ports combined with these to expand public expenditures during 1975-79.

Meanwhile, the agricultural sector was consciously neglected, with the result that there was increased food dependency. Nigeria's food import bill which was about-^ ${ }^{\wedge} 57$ million in 1970 had exceeded Nl billion in 1977. This meant that a large portion of the federal budgets was devoted to food import. And this, was done mainly to placate the organised urban workers (middle class) who were adversely affected by the escalating food prices. To further please labour, the minimum wage in the public sector was raised from N720 per annum to N1,200 per annum. Simultaneously, the N100 million Operation Feed the Nation (OFN) was launched in 1976. In pursuance of this, the military government expended millions of naira to import fertilisers.

The Keynesian public-expenditure-led growth of the military government had little regard for the absorptive capacity of the economy. Consequently, State outlays were pushed beyond the limits that could be sustained by the available resources, as revealed by persistent budget deficits in the four years, 1975/78. The cumulative fiscal deficit during this period was about N4.8 billion, an average of N1.2 billion yearly. Despite the fact that the federally collected revenue (and federally retained revenue) plummeted in 1978 (due to oil glut), State expenditure did not decline. Probably as a result of the fiscal gap, the military government went to Euro-dollar market to secure two huge loans of about N2.0 billion. Thus, the current debt crisis is often traced to the action of the federal military government.

It is important to note that part of the budget deficit was financed from bank credit. The vast expansion of bank credit accelerated the inflationary spiral which, in turn, escalated the costs of executing projects.

The undemocratic character of the military regime under which a low premium was placed on the principle of public accountability made it difficult to check state expenditure. One area in which such checks appeared not to have existed was in defence spending. The absolute magnitude of defence and internal security recurrent expenditure rose precipitously from N32.3 million in 1964/65 to N299.2 million in the 1969/70 fiscal year. Defence expenditure, on the average, increased thereafter and stood at more than Nl.O billion by 1979/80. As a proportion of current federal expenditure (see Table 3), defence spending rose from $10.4 \%$ in $1964 / 65$ to $44.1 \%$ in $1969 / 70$, declined gradually to $23.1 \%$ in $1974 / 75$, and rose again to about $32 \%$ in 1978/79.,

As noted earlier, the civil war greatly expanded defence expenditures. Prior to the achievement of political independence in 1960, the full cost of the army and defence services was borne largely by Britain. ${ }^{1}$ But, with independence, Nigeria had to bear the full cost of defence and internal security. After 1970, the absolute magnitude of defence spending was on the increase (though, its shares in total expenditures decreased), even though a substantial number of the army was demobilised after the civil war. One plausible explanation offered for this was the increased number of army officers which raised the wage bill of the armed forces ${ }^{18}$. Moreover, emphasis shifted to the building of barracks and the acquisition of sophisticated weapons. 
54 Annuls of the Social Science Council of Nigeria. No.4. 1992.

It has been argued that the rise in defence budgets long after the war is explained partially by the poverty theory of social behaviour, a situation whereby the politically powerful group, but often the minority, manipulate the allocation of scarce national resources to its advantage, but to the detriment of the mass majority of the people ${ }^{19}$

\section{CIVILIAN EXPENDITURES, 1960/65 AND 1979/83}

Up till 1983, independent Nigeria had been under civil rule for ten years (1960/65 and 1979/83). During the first civilian administration (1960/66), the federal government was concerned with how to accelerate the process of economic growth and development, with the process of political decision making taken over by Nigerians. Thus, the need to equip the country with administrative facilities necessary for nation building, for instance, raised public spending from N162 million in 1960 to approximately N237 million by 1965 . The creation of the Mid-Western Region (now Edo/Delta States) out of the old Western .Region (in 1963) required the extension of administrative facilities to the new region. Together with this was the expansion of the State's bureaucracy. These and other factors acted collectively to influence budgets at the centre. A remarkable development in the early 1960s was the launching of the 1962/68 National Development Plan. The execution of the N 1.35 billion plan had a substantial 'impact on actual federal outlays.

At the lime of handing over to the civilian administration on 1st October, 1979, the military regime had accumulated an external debt of approxi-mately-N-1.26 billion. In consequence, interest charges and principal on this loan decidedly increased and this was reflected in transfer expenditures. With the civilian government controlled by die National Party of Nigeria (NPN), Stale expenditures further escalated, as a result of several factors. Actual federal expenditure that was marginally above N7.4 billion in 1979, climbed phenomenally to over N14.1 billion the following year. But, in 1981/83, expenditures fluctuated between N9.6 billion and N13.0 billion.

The presidential system of government being experimented then provided for a bicameral legislature (the House of Representatives and the Senate). Members of the legislature placed themselves on fabulous salaries and allowances. There were several advisors and ministers, and the creation of unnecessary offices. Functions were duplicated, and those reflected significantly in recurrent expenditure which jumped from N3.2 billion in 1979, to over N6.0 billion the following year. During the same period, capital budget leaped from N4.2 billion to about N8.1 billion (about 93\% increase). The astronomical increase in capital outlay was due partly to the Green Revolution pursued through Agricultural Development Projects (ADPs) and River Basin Development Authorities (RBDAs). Added to this was the fundamental alteration of the completion time of the Federal Capital Territory, Abuja. A direct consequence of this was the award of several contracts running into billions of naira to party stalwarts.

Although, labour demanded a public sector minimum wage of N300 per month, the NPN-conlrolled government of Shagari only raised it from N100 to N125 per month in 1980'" Increasingly, expenditures on transfers became significant, as external debt charges increased dramatically from about N278 million in 1980 to N 1.1 billion three years later. 
The Shagari government had qualitative education as one of its cardinal programmes. In pursuance of this, a number of federal universities, polytechnics, colleges of education and other educational institutions were established. Budgetary allocations to education were accordingly raised. Relatedly, the capital expenditure on health increased from N41 million to N304.5 million between 1979 and 1981, and declined precipitously for the rest of the civilian administration. In general, budgetary allocation to the health sector on a yearly basis during the Second Republic was higher than allocations to the sector under the military.

Unfortunately, the upsurge in aggregate demand that was as a result of the expansion of State expenditure, far exceeded revenues, thereby generating persistent budget deficits. The cumulative fiscal deficit in the four-years 1980/83 was about N16.1 billion. A large size of public expenditures leaked out of the economy in the form of imports, particularly food and other consumer goods, because of the limited elasticity of supply. Persistently, the current account recorded deficits during 1980/83 and this was a dramatic manifestation of increased demand. One major conclusion from this is that there was a systematic correlation between the current account deficits and budget deficits (caused by the unprecedented growth of public expenditure) during the period.

A statement on the impact of corruption and extravagant spending on the overall public outlay is basic. Figures from a content analysis in the period 1978 through 1982 reveal that fraud, bribes and kickbacks, direct stealing and extravagant expenditures in government and government organisations cumulated to almost-N6.0 billion.' ${ }^{2}$ These corrupt practices were common among top military brass, bureaucrats, politicians, professionals and even technocrats who interchange the machinery of the State as part of the military-commercial complex. As these group of people engaged in private accumulation through the manipulation of public expenditures, little or no effort was made to develop the productive base of the economy (this was not the case during the colonial rule). This situation has been described as pirate capitalism which has intensified since the oil boom.

During 1980/83, the mean annual recurrent defence and internal security budget was approximately N1.4 billion. As a percentage of total recurrent outlays, it declined from $23.5 \%$ in 1980 to about $19 \%$ in 1982 and jumped to almost $25 \%$ in 1983. Perhaps, we should note that the high defence budgets in the Second Republic graphically demonstrate that the regime could have been backed by the military.

\section{CONCLUDING REMARKS}

As the statistics reveal, State expenditures in Nigeria vastly expanded since 1960. The need to speed up the process of economic development and the civil war were the major factors responsible for growth of public spending in the first United Nations development decade. Oil affluence was the single most important factor responsible for the dramatic leap of State outlays in the 1970s, a period controlled almost entirely by the military government. The need to meet overdue expenditures (delayed by the civil strife), the raising of 
public sector wages and the commitment to reconstruction programmes facilitated by oil revenues were some of the factors responsible for increased public spending. The growth of defence spending was particularly significant, despite the fact that a substantial number of soldiers were demobilised in the 1970s. Three key factors which accounted for this were the rising number of high-ranking officers, the building of army barracks and the acquisition of weapons.

Growth of public expenditures during the Shagari administration was due partly to commitment to party programmes and the creation of several unnecessary bureaucratic offices which led to the appointment of a substantial number of ministers and advisers. Fraudulent practices, kickbacks and extravagance acted significantly to raise federal budgets both under the military and the civilian regimes. In the process, budgetary allocations to vital sectors of the economy declined. 


\section{NOTES AND REFERENCES}

1. See, for example, S.E. Omoruyi (1979): "Patterns of Current Expenditures in Nigeria, 1950/51 - 1950/75", in Central Bank of Nigeria, Economic and Financial Review, Vol. 17, pp. 28-45; and J.B. Longe (1984): "The Growth and Structure of Federal Expenditure in Nigeria", in Tlie Nigerian Journal of Economic and Social Studies", Vol. 26, pp. 85-105.

2. On the validation of Wagner's Law in Nigeria, See Gini F. Mbanefoh (1980): "The Civil War and Its Impact on Government Expenditure in Nigeria". Mimeograph, Department of Economics, University of Ibadan, Nigeria; and P.O. Egwaikhide (1984): "Patterns of Government Revenue and Expenditure in Nigeria: A Historical Survey". An unpublished M.Sc. thesis submitted to the Department of Economics, University of Ibadan, Nigeria.

3. A.T. Peacock and J. Wiseman (1961): The Growth of Public Expenditure in the United Kingdom, (London: Oxford University Press), and Egwaikhide, ibid.

4. During the civilian era (1979/83), capital expenditures were less than recurrent outlays. This may have been due partly to increased employment in the public sector. It will be recalled that the Shagari government had over 40 ministers.

5. See Egwaikhide, op. cit. chapt. 4.

6. The cumulative fiscal deficit during 1966/70 was approximately N769 million. Few studies have revealed that the civil war was deficit-financed. For example, see O. Aboyade and A. Ayida (1971): "The War Economy in Perspective", in Tlie Nigerian Journal of Economic and Social Studies, Vol. 13, pp. 13-37; and T.A. Oycjide (1986): "Sector Proportion and Growth in the Development of the Nigerian Economy", a paper presented in Session Two, International Economic Association Annual Conference, New Delhi, India, December $1-5$.

7. This was due to the Middle East Crisis (1973/74). As a result, average export price per barrel of Nigerian crude oil leaped from US\$4.1 in 1973 to US\$11.85 in 1975.

8. On this, see A. Iwayemi (1981): "Planning and Performance in the Nigerian Petroleum Industry", a paper presented at the Annual Conference of the Nigerian Economic Society, Ilorin, May 1986.

9. See B. Onimode (1983): Imperialism and Underdevelopment in Nigeria, (London: Macmillan), p. 210; and G. Williams, (1976): "Nigeria: A Political Economy", in G. Williams, (ed) (1976): Nigeria: Economy and Society, London, Rex Collings, p. 32.

10. Ibid.

11. S.B. Falegan (1979): "Trends in Nigeria's Balance of Payments,, and Policy Measures Needed for Self-Reliance", in NISER (ed) (1979): Self-Reliance and Self-Sufficiency: An Appraisal of the Nigerian Case, Ibadan: The Nigerian Institute of Social and Economic Research, NISER, p. 7. 
58 Annals of the Social Science Council of Nigeria, No. 4, 1992.

12. See H. Bienen (1983): "Oil Revenues and Policy Choice in Nigeria," in World Bank Working Paper, No. 592.

13. Iwayemi, op. cit.

14. T. Turner (1977): "Two Refineries: A Comparative Study of Technology Transfer to the Nigerian Refining Industry", in World Development, Vol. 15, pp. 235-56.

15. See M.O.A. Adejugbe (1980): "Nigeria's Industrial Policies and Performance in the Military Era, 1966-1979", in Proceedings of the 1980 Annual Conference of the Nigerian Economic Society, pp. 232-37.

16. S.B. Falegan (1978): "External Borrowing and Public Policy", in The Nigerian Institute of International Affairs Lecture Series, No. 26, pp. 7-8.

17. P.N.C. Okigbo (1965): Nigerian Public Finance, Evasion: North Western University Press, p. 181.

18. Promotion, pay-jumps and back-pays and other factors were responsible. On this, see J. Bayo Afleskson (1978): "Nigerian Military and Social Expenditures: 1970-1976", in Proceedings of the 5th Annual Conference of the Nigerian Political Social Association, pp. 246-64; and Onimode, op. cit., p. 214.

19. Mbanefoh, op. cit.

20. See T. Forrest (1986): "The Political Economy of Civil Rule and the Economic Crisis in Nigeria (1979-1984)", in Review of African Political Economy, No.35, p. 18.

21. On this issue, see Schatz, P. Sayre (1984): "Pirate Capitalism and the Inert Economy of Nigeria", in Journal of Modem African Studies, No. 1, pp. 45-57.

22. Festus lyayi (1986): "The Primitive Accumulative in Neo-Colony: The Nigerian Case", in Review of African Political Economy, No. 35, pp. 34-35.

23. Frank has argued that there is emergence of military-industrial complex in the Third World. On this issue, see A.G. Frank (1981): Crisis: In the TJiird World, New York and London: Holmes and Meier Publishers, pp. 260-64.

24. Schatz, op. cit. 
State Expenditure in Nigeria: A Historical Sketch 59

\section{APPENDIX}

\section{Table 1}

\section{TOTAL GOVERNMENT EXPENDITURES AND GROSS DOMESTIC (GDP) AT CURRENT PRICES, (1961-1983)}

\begin{tabular}{l|l|l|l}
\hline Year & $\begin{array}{l}\text { Gross Domestic } \\
\text { Product }\end{array}$ & $\begin{array}{l}\text { Total } \\
\text { Government } \\
\text { Expenditures }\end{array}$ & $\begin{array}{l}\text { Government } \\
\text { Expenditures as } \\
\text { percentage of } \\
\text { GDP }\end{array}$ \\
\hline 1961 & $2,247.4$ & 336.6 & 15.0 \\
1965 & $2,289.4$ & 465.3 & 15.5 \\
1970 & $3,549.3$ & $1,086.4$ & 30.6 \\
1975 & $8,915.1$ & $6,474.5$ & 46.5 \\
1980 & $45,950.6$ & $16.126 .9^{1}$ & 35.1 \\
1983 & $56,204.19$ & $23,177.0$ & 41.2 \\
\hline
\end{tabular}

Source: Federal Office of Statistics, Annual Abstract of Statistics, various years, Lagos. 
60 Annals of the Social Science Council of Nigeria, No.4,1992.

Table 2

FEDERAL GOVERNMENT EXPENDITURES IN NIGERIA, 1960/1983

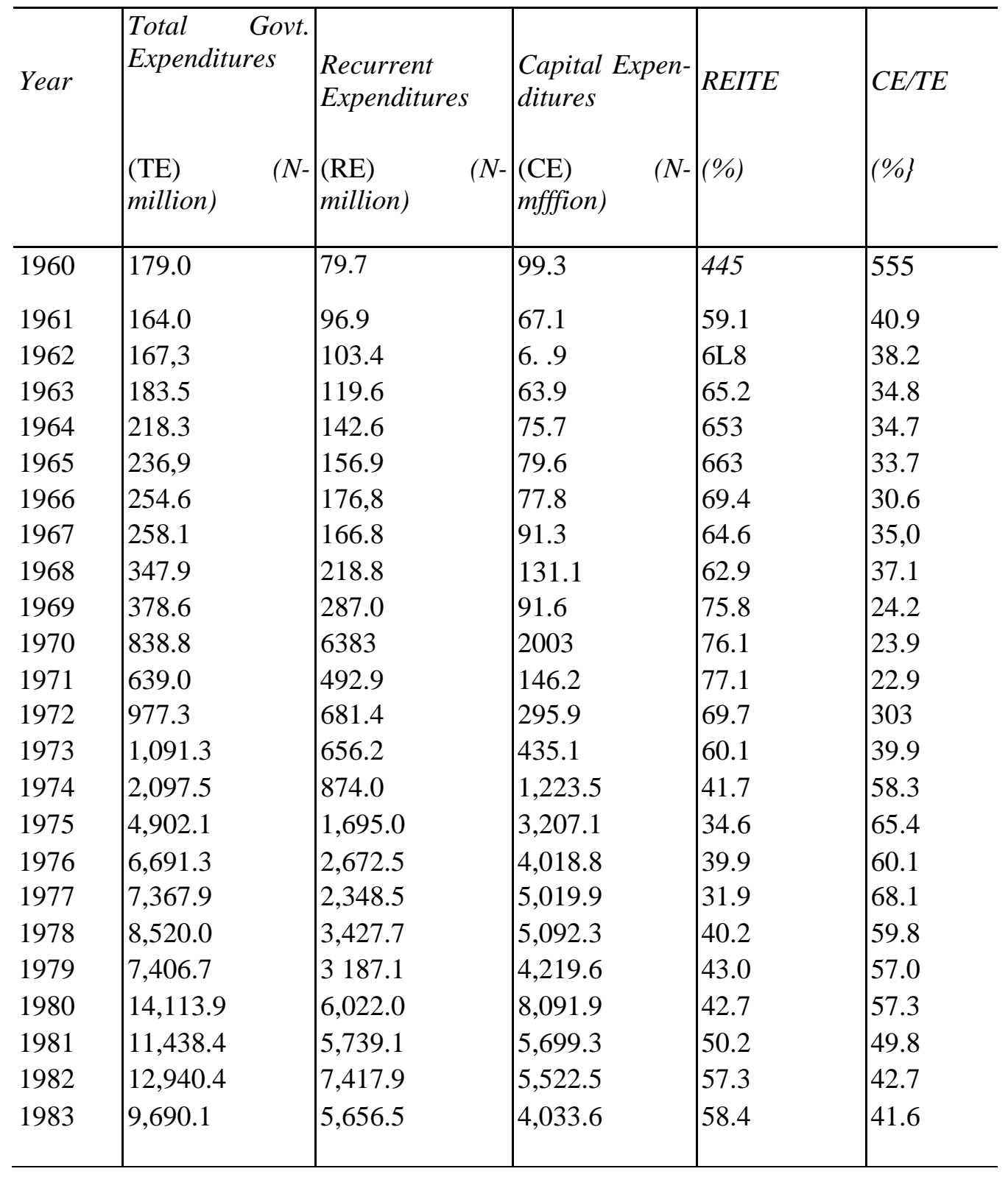

Sources: (i) Central Bank of Nigeria, Annual Report and Statement of Account, various issues, Lagos.

(ii) Central Bank of Nigeria, Nigeria's Principal Economic and Financial Indicators 1970-1987, Lagos. 
State Expenditure in Nigeria: A Historical Sketch 61

Table 3

\section{FEDERAL GOVERNMENT RECURRENT EXPENDITURES ON DEFENCE AND INTERNAL SECURITY, 1964/65-1983}

\begin{tabular}{|c|c|c|c|}
\hline Year & $\begin{array}{l}\text { Total Recurrent } \\
\text { Expenditures } \\
(N-\text { million) }\end{array}$ & $\begin{array}{l}\text { Defence and Internal } \\
\text { Security Outlays } \\
(N \text {-million) }\end{array}$ & \begin{tabular}{|lrr} 
Defence & and & Internal \\
Security & as & as \\
Percentage & & of \\
Recurrent Expenditures
\end{tabular} \\
\hline $1964 / 65$ & 308.2 & 32.2 & 10.4 \\
\hline 1965/66 & 293.8 & 34.8 & 11.8 \\
\hline $1967 / 68$ & 307.2 & 58.2 & 18.9 \\
\hline $1968 / 69$ & 379.2 & 121.6 & 32.1 \\
\hline $1969 / 70$ & 626.8 & 2762 & 44.1 \\
\hline 1970/71 & 7825 & 296.2 & 37.9 \\
\hline $1971 / 72$ & 878.4 & 299.2 & 34.1 \\
\hline $1972 / 73$ & $1,178.4$ & 403.2 & 34.2 \\
\hline $1973 / 74$ & $1^{\wedge} 17.3$ & 393.2 & 29.9 \\
\hline $1974 / 75$ & $1,959.2$ & 453.1 & 23.1 \\
\hline $1975 / 76$ & - & 774.4 & - \\
\hline 1976/77 & $2,672.5$ & 690.0 & 25.8 \\
\hline $1977 / 78$ & $2,907.0$ & 929.0 & 32.0 \\
\hline 1978/79 & $2,528.0$ & 801.0 & 31.6 \\
\hline $1979 / 80$ & $3,961.0$ & $1,034.0$ & 26.1 \\
\hline 1980 & $5,975.0$ & $1,401.0$ & 23.5 \\
\hline 1981 & $7,063.4$ & $1,407.3$ & 23.5 \\
\hline 1982 & $7,358.2$ & $1,392.5$ & 18.9 \\
\hline 1983 & $5,624.3$ & $1,381.7$ & 24.6 \\
\hline
\end{tabular}

Sources: $\quad$ (i) Omoruyi (1979), p. 37.

(ii) Federal Office of Statistics, Economic and Social Statistics. Bulletin, 1986 Edition, Lagos. 